Kastamonu Eğitim Dergisi
Kastamonu Education Journal

\title{
Pedagojik Formasyon Eğitimi Alan Tarih Öğretmen Adaylarının Öğretmenlik Mesleğine İlişkin Tutumları
}

\section{Attitudes of History Teacher Candidates Who Took Pedagogical Formation Education towards Teaching Profession}

\section{Öz}

\author{
Tuba ŞENGÜL BIRCAN ${ }^{1}$
}

Araştırma, tarih öğretmen adaylarının öğretmenlik mesleğine ilişkin tutumlarını belirlemek amacıyla, nicel araştırma yöntemlerinden betimsel tarama modeli kullanılarak yapılmıştır. Çalışma, 2014-2015 eğitim-öğretim yılında İç Anadolu Bölgesinde yer alan bir üniversitenin Edebiyat fakültesinde öğrenim gören 115 tarih öğretmen adayı ile hayata geçirilmiştir. Çetin (2006) tarafindan geliştirilen "Öğretmenlik Mesleğine Yönelik Tutum Ölçeği" kullanılmıştır. $5^{\prime}$ li likert olarak hazırlanan ölçek 35 maddeden oluşmuştur. Ölçeğin Cronbach-alpha güvenirlik katsayısı 0,96 olarak belirlenmiştir. Araştırma verilerinin analizinde SPSS (23.0) paket programından yararlanılmış ve gerekli istatistiki teknikler kullanılarak analizler yapılarak, sonuçlar yorumlanmıştr. Çalışma sonucunda öğretmen adaylarının öğretmenlik mesleğine ilişkin tutumlarının cinsiyete ve mesleği seçme nedenlerine göre anlamlı farklılık gösterdiği saptanmıştr.

Anahtar Kelimeler: Tarih öğretmen adayları, öğretmenlik mesleği, tutum

\section{Abstract}

The aims of this research is to determine the attitudes of history teacher candidates towards teaching profession. The study conducted using survey method from quantitative research approaches. This study was carried out with 115 history student teacher who are the faculty of Letters of in a university in the central Anatolia Region at 2014-2015 academic year. Teaching professional attitude scale developed by Çetin (2006) was used as data collection tool. The scale has 35 items consisting 5 likert type, In the scale, Cronbach-alpha reliability coefficient is as 0,96 was determined. Data were analyzed by using the statistical package SPSS (23.0). In the result of research have been found candidate teachers' atitudes towards teaching profession was differed significantly by gender and the reason of choosing a teaching profession

Keywords: History teacher candidates, teaching profession, attitude. 


\section{Extended Summary}

Choice of profession is a turning point for a person. The person chooses a lifestyle when he chooses the profession. The profession becomes a part of the identity of the individual and constitutes the communication, dignity and status at the society of him. Teacher candidates' education is among the factors who influence their attitudes toward the profession and the attitudes of theirs affect the quality of the profession and future of the country. Therefore, it is important to determine the attitudes of prospective teachers to the profession in order to take the necessary precautions before starting work. The attitudes of teacher candidates towards the profession must be known and evaluated so that a positive attitude towards the teaching profession can be developed. The attitudes of history teacher candidates towards teaching profession have not been investigated before. For this reason, the study was deemed necessary. In this study, which examines the attitudes of the history teacher candidates toward the profession was searched answer "Does the attitudes of history teacher candidates towards the teaching profession differ according to their gender?", "Are the history teacher candidates' attitudes towards the teaching profession differ according to their reasons for choosing a profession?"

Method: The aims of this research is to determine the attitudes of history teacher candidates towards teaching profession. The study conducted using survey method from quantitative research aproaches. This study was carried out with 115 history student teacher who are a university in the central Anatolia Region at 2014-2015 academic year. Teaching professional attitude scale developed by Çetin (2006) was used as data collection tool. the scale has 35 items 15 of which are negative and 20 of which are positive consisting 5 likert type. There are three subdimensions: love, value and adaptation. High score shows positive attitude, low score shows negative attitude. In the scale, Cronbach-alpha reliability coefficient is as 0,96 was determined. Data were analyzed by using the statistical package SPSS (23.0).

Findings: It has been determined that the history teacher candidates in the study group have a positive view on the teaching profession in general terms according to the scores obtained from the teaching profession attitude scale. It can be said that adaptation and love toward the teaching profession of Candidates of Female history teacher higher than male history teacher who are involved in the study. In this case shows that girls 'attitudes are more positive than boys' attitudes. In the love subdimension, it have been detected that teacher candidates who say they have chosen a teaching profession because they love the profession have higher point than teacher candidates who say they have chosen a teaching profession because they do not want to be unemployed and because the economic conditions are good.

In the value subdimension, it have been detected that teacher candidates who say they have chosen a teaching profession because they love the profession have higher point than teacher candidates who say they have chosen a teaching profession because they do not want to be unemployed. Teacher candidates who say they have chosen a teaching profession because the economic conditions are good have higher point than teacher candidates who say they have chosen a teaching profession because they love the profession, teacher candidates who say they have chosen a teaching profession because they do not want to be unemployed, teacher candidates who say they have chosen a teaching profession because their family want and candidates marking "other" option. In the adaptation subdimension, teacher candidates who marking "other" option have higher point than teacher candidates who say they have chosen a teaching profession because they love the profession, they do not want to be unemployed and the economic conditions are good.

The expressions of teacher candidates who marking "other" option: All of them, the closest profession to me, it has wide working area, the most loving profession, luck and fortune and I chose because of been a profession that meets people's needs. It was also determined that the interpretations there are mostly expressions embracing the profession.

A study conducted by Aksoy (2010) showed that candidates who choose to teach as a teacher have a higher attitude towards the profession. Another study conducted by Özder, Konedralı and Zeki (2010) also suggests that the candidates who are willing to become teachers have higher attitude scores than teacher candidates who say they have chosen a teaching profession because they do not want to be unemployed and the economic conditions are good. In the study conducted by Kyriacou and Kunc (2007), it was concluded that the economic benefits of the profession were effective in determining the teachers' attitudes towards the profession. As a result, it was determined that the formation program students' attitudes towards the teaching profession were high. Similar results were obtained with in the academic studies. According to the research result; it is striking that the attitudes of the students in the formation program towards the teaching profession are high in the positive direction. It is not wrong to say that even though the missions of the literary faculties are not intended to raise teachers, the ultimate goal of the students who prefer these faculties is to become teachers. In addition, the hope that these students can enroll in the pedagogical formation program and hope that be employed as teachers increases the motivation of the teacher candidates and their attitudes towards the profession positively. We can say that the training of the formation also contributes to the attitudes of the prospective teachers towards the teaching profession.

Teaching requires consciousness as a profession and it is expected that the individuals who choose this profession will work very well for this profession. For this reason, those who choose the profession and those who are directed to the profession should enter this process from early ages and be educated with the necessary consciousness. "You can't teach an old dog new tricks" proverb should not be forgotten, especially for the teaching profession.

In line with these results, the following suggestions are presented.

- It will be useful to repeat the work at different universities and compare the results.

- A path map should be drawn to those who want to be a teacher from secondary school by following a planned, programmed and systematic way of teacher training.

- It is important to consider the attitudes towards the profession as well as the academic achievement points in the selection of the teaching profession.

- History teacher candidates' attitudes towards the teaching profession should be encouraged and encouraged to study history teaching from the first years of undergraduate education in order to develop positively. 


\section{Giriş}

Meslek seçimi insan hayatında bir dönüm noktasıdır. Kişi, seçeceği meslekle birlikte hayat tarzını belirler, geleceğine yön verir. Meslek, bireyin kimliğinin bir parçası haline gelerek toplumdaki iletişimini, saygınlığını ve statüsünü oluşturur. Yetenekler ve istekler doğrultusunda seçilen meslek, mutluluğu ve başarıyı getirirken; aksi durum körelme ve depresyonu tetikler (Sayar, 2017). Bireylerin duygusal durumları tüm yaşamlarına yansıyarak iş verimleri üzerinde de etkili olur. Bu sebepledir ki, meslek seçimi önemsenmesi gereken bir tercihtir. Çünkü toplumların gelişimi, toplumu oluşturan bireylerin doğru meslek seçimi ve istihdamıyla garantilenebilir.

1739 sayılı Milli Eğitim Temel Kanununun 43. maddesinde; “Öğretmenlik mesleği, devletin eğitim-öğretim ve bununla ilgili yönetim görevlerini üzerine alan özel bir ihtisas mesleği" olarak tanımlanmakta ve öğretmenlerin bu görevlerini Türk Milli Eğitiminin amaçlarına ve ilkelerine uygun olarak ifa etmekle yükümlü oldukları vurgulanmaktadır (MEB, 1739). Bir intisas mesleği olduğuna dikkat çekilen öğretmenlik mesleğini icra eden öğretmenlerin başarısı eğitim sisteminin başarısıyla doğru orantılıdır. Eğitim ve öğretimde hedefler ve içerik ne kadar birbiriyle uyumlu ve kusursuz olursa olsun, o hedef ve içerikleri aktaracak kaliteli öğretmen yoksa tüm emekler boşa gidecektir (Ocak, 2016). Millî Eğitim Bakanlığı tarafindan belirlenen performans göstergelerinde yer alan öğretmen yeterlikleri; kişisel ve mesleki değerler (mesleki gelişim), öğrenciyi tanıma, öğretme ve öğrenme süreci, öğrenmeyi-gelişimi izleme ve değerlendirme, Okul-aile ve toplum ilişkileri, program ve içerik bilgisi şeklinde sınıflanmışken (MEB ÖYGGM., 2017) eğitim literatürüne bakıldığında öğretmenlerde bulunması gereken özellikler alan bilgisi, genel kültür ve öğretmenlik meslek bilgisi (ilhan, 2004; Demirel, 2009) şeklinde üç gruba ayrılmıştrr. Kâğıt üzerinde yapılan bu çalışmaların okullara yansıması ve ülke eğitimine katkı sağlayabilmesi ancak konuya duyarlı, kendini yetiştirme bilinci içinde olan, mesleğine karşı olumlu algılara sahip öğretmenlerle mümkündür. Bu sebeple öğretmen eğitimi ve öğretmen adaylarının algıları önemlidir. Mesleğe yönelen adayların algılarının zaman zaman sorgulanması ve yol haritasında gereken düzenlemelerin belirlenerek, işe koşulması öğretmenlik mesleğinin gelişimini sağlayacaktır.

Tutum, bir bireyin nesnelere, insanlara, yerlere, olaylara ve fikirlere yönelik lehte veya aleyhte gerçekleşen duygusal eğilimidir (Papanastasiou, 2002). Kağıtçıbaşı (1988)'na göre tutum, bir bireye atfedilen ve onun bir psikolojik obje ile ilgili duygu, düşünce ve davranışlarını düzenli bir biçimde oluşturan yönelimdir. Öğretmenlik mesleğine ilişkin tutum, kişinin öğretmenlik meslek algısını yansıtmakta; tutumun oluşması ise öğrencilik yıllarından başlamaktadır. Ayrıca öğretmenlik mesleğine ilişkin tutum ve algıların belirlenmesinin kişilerin meslekte sağlayacağı başarıyı göstermesi açısından ve öğretmenlik mesleğinin gelişimine katkı sağlaması yönünden yararlı olacağı muhakkaktır. Öğretmen yetiştirme programlarının görevlerinden biri hatta en önemlisi öğretmenliğe ilişkin tutumların belirlenmesi, öğretmen adaylarına bunların nasıl kazandırılacağının saptanması ve sonucun olumlu ve olumsuz yönlerinin değerlendirilmesidir. Kısacası bir öğretmenin mesleğe yönelik tutumu, başarısının anahtarıdır. Başarılı bir öğretmenin kişisel ve mesleki özeliklerinden birkaçını vurgulamak olumlu tutum takınan öğretmenin yaklaşımını da göstermek açısından yararlı olabilir. Mesleğe yönelik olumlu tutum takınan öğretmen (Eraslan ve Çakıcı, 2011), alan bilgisi açısından yeterlidir ve kendini sürekli geliştirir; sabırlı davranır, olaylar karşısında dayanıklıdır ve duygularını kontrol altında tutar; farklı inanç, görüş ve gruplara saygılı ve uzlaştırıcıdır; eleştiriye açıktır; öğrencileri güdüleyici özelliklere sahiptir; öğrencilere karşı güvenilir, dürüst, objektif, sırdaş, dost, güler yüzlü, hoşgörülü ve sevecendir; liderlik, arabuluculuk, hakemlik, temsilcilik özelliklerine sahiptir; öğrencileri, velileri ve çevresini etkilemede başarılıdır; öğrencilerin problem çözme, sistematik ve yaratıcı düşünme becerilerini geliştirmeye çalışır; öğrendiklerini uygulamaya aktarabilen bireyler yetiştirir; öğrencileri bir üst öğrenime, topluma ve hayata hazırlamaya çalışır; öğretim ve öğrenmeyle ilgili son gelişmeleri izler ve sınıfta uygulamaya çalışır. Bu yeterlikleri sağlamak için, öğretmenlerin eğitim sisteminin amaçlarını iyi kavramış, bu amaçlara gidecek yolları doğru tayin etmiş ve mesleğe pek çok yönden iyi hazırlanmış olmaları gerekmektedir. Öğretmen adaylarının mesleğe yönelik tutumlarının bilinmesi ve değerlendirilmesi; öğretmenlik mesleğine yönelik olumlu yönde tutum geliştirilebilmesini olanaklı kılabilir. Tarih öğretmen adaylarının öğretmenlik mesleğine ilişkin tutumlarııın daha önce spesifik olarak araştırılmamış olması da çalışmayı gerekli kılmıştır.

Tarih öğretmen adaylarının mesleğe ilişkin tutumlarının incelendiği bu çalışmada aşağıdaki alt amaçlar sorgulanmıştr.

1. Tarih öğretmen adaylarının öğretmenlik mesleğine yönelik tutumları cinsiyetlerine göre farklılaşmakta mıdır?

2. Tarih öğretmen adaylarının öğretmenlik mesleğine yönelik tutumları mesleği seçme nedenlerine göre farklılaşmakta mıdır? 


\section{Yöntem}

\subsection{Araştırmanın Modeli}

Tarih öğretmen adaylarının öğretmenlik mesleğine ilişkin tutumlarının incelendiği bu araşttrma betimsel (Karasar, 2016) nitelikli bir çalışmadır. Araştırmada tarama modeli kullanıımıştır. Karasar’a (2016) göre, tarama modelleri var olan durumu var olduğu şekliyle betimlemeyi amaçlayan araştırma yaklaşımıdır.

\subsection{Araştırma Grubu}

Çalışma, 2014-2015 eğitim-öğretim yılında İç Anadolu Bölgesinde yer alan bir üniversitede gerçekleştirilmiştir. Araştrrma grubunu, Edebiyat Fakültesi'ne formasyon eğitimi almak üzere kayıt yaptran 115 tarih öğretmeni adayı oluşturmuştur. Araştırmaya kațlan tarih öğretmeni adayları aynı kurumdan mezun olmuş ve formasyon eğitimi almak üzere yine aynı kuruma kayıt yaptırmışlardır. Çalışmanın ölçeği, katılımcılara formasyon eğitimlerinin son ayında uygulanmıştr.

Tablo 1. Araştırma Grubunda Yer Alan Öğretmen Adaylarına iliş̧in Betimsel Bilgiler

\begin{tabular}{lcc}
\hline Cinsiyet & $\mathrm{n}$ & $\%$ \\
\hline Erkek & 55 & 47,8 \\
Kadın & 60 & 52,2 \\
\hline Mezun Olunan Lise & $\mathrm{n}$ & $\%$ \\
\hline Genel Lise & 90 & 78,3 \\
Meslek Lisesi & 10 & 8,7 \\
Anadolu Lisesi & 13 & 11,3 \\
Diğer & 2 & 1,7 \\
\hline Mesleği Seçme Sebebi & $\mathrm{n}$ & $\%$ \\
\hline Sevdiğim için seçtim. & 63 & 54,8 \\
Boşta kalmamak için seçtim. & 29 & 25,2 \\
İmkânları için seçtim. & 10 & 8,7 \\
Ailem istediği için seçtim. & 8 & 7,0 \\
Diğer & 5 & 4,3 \\
\hline TOPLAM & 115 & 100 \\
\hline
\end{tabular}

\subsection{Veri Toplama Araçları}

Çalışmada yer alan öğretmen adaylarının mesleğe ilişkin tutumlarını belirlemek amacıyla bir kişisel bilgi formu ve bir de tutum ölçeği formu kullanılmıştı. Çetin (2006) tarafindan geliştirilen cronbach-alpha güvenirlik katsayısı 0,96 olarak hesaplanmış olan "Öğretmenlik Mesleğine Yönelik Tutum Ölçeği" araştırmada kullanılmıştır. 5’li likert olarak hazırlanan ölçek 15'i olumsuz 20'si olumlu olmak üzere toplam 35 maddeden oluşmaktadır. “Öğretmenlik Mesleğine Yönelik Tutum Ölçeği” nin sevgi, değer ve uyum olmak üzere 3 alt boyutu bulunmaktadır. Yüksek puan olumlu tutumu, düşük puan olumsuz tutumu göstermektedir.

\subsection{Verilerin Analizi}

Araştırma verilerinin istatistiksel analizlerinde SPSS (23.0) paket programı kullanılmış, betimsel istatistik yöntemlerinden (f) frekans, (\%) yüzde ve $(\overline{\mathrm{X}})$ aritmetik ortalama hesaplanmıştır. Bağımsız değişkenler arasındaki farklılıkların tespit edilmesinde t-Testi (cinsiyet karşılaştırması için) ve ANOVA (meslek seçimi nedenleri karşılaştırması için) testlerinden yararlanılmıştı. İkiden fazla grubun karşılaştırıldığı durumlarda Levene testi sonucunun anlamlı çıkması halinde ilişkisiz ölçümler arasındaki ilişkileri tespit edebilmek için kullanılan parametrik olmayan Kruskal Wallis $\mathrm{H}$ testi kullanılmıştır. Kruskal Wallis $\mathrm{H}$ testi sonucunun anlamlı çıktı̆ı durumlarda ise gruplar arasındaki farkın kaynağını belirlemek amacıyla grupların ikili kombinasyonları üzerinden Mann Whitney $U$ testi uygulanmıştır. Sonuçlar tablo haline getirilerek yorumlanmış ve bulgular bölümünde sunulmuştur. Bağımsız değişkenler arasında anlamlı bir farklılık olup olmadığını belirlemek amacıyla $\alpha=0,05$ düzeyinde test edilmiştir.

\section{Bulgular}

Araştırmanın bu bölümünde, tarih öğretmen adaylarının mesleki tutumlarına ilişkin nicel veriler, "cinsiyet" ve "meslek seçim nedeni" değişkenlerine göre tablolaştrılarak yorumlanmıştır. 
Tarih öğretmeni adaylarının "cinsiyet" değişkenine ilişkin bulguları aşağıda verilmiştir.

Tablo 2. Cinsiyet Değişkenine iliş̧kin T-Testi Sonuçları

\begin{tabular}{|c|c|c|c|c|c|c|c|c|c|c|c|}
\hline \multirow{3}{*}{ Alt Boyut } & \multicolumn{6}{|c|}{ Cinsiyet } & \multirow{3}{*}{$d$} & \multirow{3}{*}{$\mathrm{t}$} & \multirow{3}{*}{$p$} & \multirow{2}{*}{\multicolumn{2}{|c|}{ Homojenlik }} \\
\hline & \multicolumn{3}{|c|}{ Erkek } & \multicolumn{3}{|c|}{ Kadın } & & & & & \\
\hline & $\mathrm{N}$ & $\bar{X}$ & $\mathrm{~s}$ & $\mathrm{~N}$ & $\overline{\mathrm{X}}$ & $\mathrm{s}$ & & & & Levene & $\mathrm{p}$ \\
\hline Sevgi & 55 & 3.54 & 0.59 & 60 & 4.24 & 0.45 & 113 & $-7.135^{*}$ & .000 & 7.520 & .007 \\
\hline Değer & 55 & 4.22 & 0.83 & 60 & 4.57 & 0.44 & 113 & $-2.810^{*}$ & .006 & 20.886 & .000 \\
\hline Uyum & 55 & 3.37 & 0.67 & 60 & 4.26 & 0.37 & 113 & $-8.638^{*}$ & .000 & 21.835 & .000 \\
\hline
\end{tabular}

Tablo 2 incelendiğinde tarih öğretmeni adaylarının "Öğretmenlik mesleği tutum ölçeği”ne verdikleri yanıtların 3 alt boyut düzeyinde hesaplandığı görülecektir. Analiz sonuçlarına göre "sevgi" [ $\left.t_{(113)}=-7.135 ; p>0.05\right]$, "değer" [ $t_{(113)}$ $=-2.810 ; p>0.05]$ ve "uyum" [ $\left.\mathrm{t}_{(113)}=-8.638 ; \mathrm{p}>0.05\right]$ alt boyutlarında tarih öğretmeni adayları arasında "cinsiyet" değişkenine ilişkin anlamlı bir farklılık gözlenmektedir. Öğretmenlik mesleği tutum ölçeğinin sevgi alt boyutunda erkek öğretmen adayları 'kathlıyorum' ( $\overline{\mathrm{X}}=3.54)$ düzeyinde görüş bildirirken, kadın öğretmen adayları 'kesinlikle kathlıyorum' $(\overline{\mathrm{X}}=4.24)$ düzeyinde görüş bildirmişlerdir.

Öğretmenlik mesleği tutum ölçeğinin değer alt boyutunda ise hem erkek öğretmen adayları $(\bar{X}=4.22)$ hem kadın öğretmen adayları ( $\overline{\mathrm{X}}=4.57$ ) 'kesinlikle katılıyorum' düzeyinde görüş bildirmişlerdir.

Öğretmenlik mesleği tutum ölçeğinin uyum alt boyutunda erkek öğretmen adayları 'kathlıyorum'( $\overline{\mathrm{X}}=3.37)$ düzeyinde görüş bildirirken, kadın öğretmen adayları 'kesinlikle katılıyorum' ( $\overline{\mathrm{X}}=4.26)$ düzeyinde görüş bildirmişlerdir.

Ancak öğretmenlik mesleği tutum ölçeğinin sevgi, değer ve uyum alt boyutlarında Levene istatistiği sonucunda maddelerin non-parametrik olduğu ve bunun sonucunda anlamlı bir farklılık görüldüğünden, üç alt boyut için parametrik olmayan Mann-Whitney U testi uygulanmıştr. Tablo 3'te tarih öğretmeni adaylarının öğretmenlik mesleği tutum ölçeğinin sevgi, değer, uyum alt boyutlarına ilişkin Mann-Whitney $\mathrm{U}$ testi sonuçları verilmiştir.

Tablo 3. Cinsiyet Değişkenine Iliş̧kin Mann-Whitney U Testi Sonuçları

\begin{tabular}{|c|c|c|c|c|c|c|c|}
\hline Alt Boyut & Gruplar & $\mathrm{N}$ & Sıralar Ortalaması & Sıralar Toplamı & M-Whitney U & Z & $p$ \\
\hline \multirow{2}{*}{ Sevgi } & Erkek & 55 & 39.13 & 2163.00 & \multirow{2}{*}{623.000} & \multirow{2}{*}{-5.760} & \multirow{2}{*}{.000} \\
\hline & Kadın & 60 & 75.12 & 4507.00 & & & \\
\hline \multirow{2}{*}{ Değer } & Erkek & 55 & 51.95 & 2857.00 & \multirow{2}{*}{1317.000} & \multirow{2}{*}{-1.893} & \multirow{2}{*}{.058} \\
\hline & Kadın & 60 & 63.55 & 3813.00 & & & \\
\hline \multirow{2}{*}{ Uyum } & Erkek & 55 & 36.96 & 2033.00 & \multirow{2}{*}{493.000} & \multirow{2}{*}{-6.527} & \multirow{2}{*}{.000} \\
\hline & Kadın & 60 & 77.28 & 4637.00 & & & \\
\hline
\end{tabular}

Araşttrmada "Öğretmenlik mesleği tutum ölçeği”nin sevgi, değer, uyum alt boyutlarında yapılan Levene istatistiği sonucunda anlamlı bir farklılık belirlendiği için parametrik olmayan t sınaması Mann-Whitney U testi uygulanmıştır. Tablo 3'teki Mann-Whitney U testine ilişkin "sevgi" alt boyutu bulguları incelendiğinde kadın tarih öğretmeni adayları lehine anlamlı bir farkın ortaya çıktığı görülmektedir $(U=623.000 p<0,05)$. Bulgulara göre, kadın tarih öğretmeni adaylarının (SO=75.12) öğretmenlik mesleğini sevme puanlarının, erkek tarih öğretmeni adaylarına $(\mathrm{SO}=39.13)$ göre daha yüksek olduğu söylenebilir.

Aynı tabloda "değer" alt boyutu bulguları incelendiğinde erkek ve kadın tarih öğretmeni adaylarının öğretmenlik mesleğine değer vermeye ilişkin puan ortalamaları arasında anlamlı bir fark gözlenmemektedir.

Tablo 3'teki Mann-Whitney U testine ilişkin "uyum" alt boyutu bulguları incelendiğinde, kadın tarih öğretmeni adayları lehine anlamlı bir farkın ortaya çıktığını göstermektedir ( $U=493.000 p<0,05)$. Bulgulara göre, kadın tarih öğretmeni adaylarının ( $\mathrm{SO}=77.28)$ öğretmenlik mesleğine uyum puanlarının, erkek tarih öğretmeni adaylarına $(\mathrm{SO}=36.96)$ göre daha yüksek olduğu söylenebilir.

Sonuç olarak, kadın tarih öğretmeni adaylarının öğretmenlik mesleğine yönelik sevgilerinin ve öğretmenlik mesleği- 
ne yönelik uyumlarının, erkek tarih öğretmeni adaylarına göre daha yüksek olduğunu söyleyebiliriz.

Tarih öğretmeni adaylarının "meslek seçim nedeni" değişkenine ilişkin araştırma bulguları da tablolar halinde aşağıda verilmiş ve yorumlanmıştır.

Tablo 4. Sevgi Boyutunda Mesleği Seçme Nedenlerine iliş̧kin Veriler

\begin{tabular}{|c|c|c|c|c|c|}
\hline Alt Boyut & Grup & Grup Adı & $\mathrm{N}$ & $\overline{\mathrm{X}}$ & ss \\
\hline \multirow{6}{*}{ 然 } & 1. & Sevdiğim için seçtim. & 63 & 4.17 & 0.52 \\
\hline & 2. & Boşta kalmamak için seçtim. & 29 & 3.53 & 0.60 \\
\hline & 3. & İmkânları iyi olduğu için seçtim. & 10 & 3.50 & 0.60 \\
\hline & 4. & Ailem istediği için seçtim. & 8 & 3.67 & 0.44 \\
\hline & \multirow[t]{2}{*}{5.} & Diğer & 5 & 3.94 & 0.81 \\
\hline & & Toplam & 115 & 3.90 & 0.63 \\
\hline
\end{tabular}

Tarih öğretmeni adaylarının mesleğe ilişkin tutum ölçeğinin "sevgi" alt boyutundan elde edilen verilerde "meslek seçim nedenleri" yönünden fark olup olmadığını incelemek amacıyla Tek Yönlü Varyans Analizi (ANOVA) yapılmıştr. Varyans analizi sonucunda tutumlarda farklılığın belirlendiği durumlarda, farklılığın hangi gruplar arasında gerçekleştiğini ortaya koymak için Kruskall Wallis-H $(\mathrm{KWH})$ çoklu karşılaştrma testi uygulanmıştı. Analizlere ilişkin veriler ve yorumlamalar aşağıda sunulmuştur.

Tablo 5. Sevgi Boyutuna iliş̧kin ANOVA Sonuçları

\begin{tabular}{lcccccc}
\hline Varyansın Kaynağı & Kareler Toplamı & sd & Kareler Ortalaması & $F$ & $P$ & Fark \\
\hline Gruplar arası & 10.683 & 4 & 2.671 & 8.422 & .000 & $1-2,1-3$ \\
Gruplar içi & 34.883 & 110 & .317 & & & \\
Toplam & 45.566 & 114 & & & & \\
\hline
\end{tabular}

Tablo 4 ve 5'te tarih öğretmeni adaylarının "Öğretmenlik mesleği tutum ölçeği"nin "sevgi" alt boyutuna ilişkin tutumları mesleği seçme nedeni faktörüne göre incelendiğinde 1. grup ile 2. grup; 1. grupla 3. grup arasında anlamlı bir farklılık görülmektedir $[F(4-110)=8.422 ; p<0.05]$. Test sonucuna göre mesleği seçme nedeni yönünden 1.grupta yer alan öğretmen adayları 'tamamen katlıyorum' $(\bar{X}=4.17)$ düzeyinde görüş bildirirken 2. grupta yer alan öğretmen adayları 'katlıyorum' ( $\overline{\mathrm{X}}=3.53)$ ve 3. grupta yer alan öğretmen adayları 'kathlıyorum' ( $\overline{\mathrm{X}}=3.50)$ düzeyinde görüş bildirmişlerdir. Bu sonuca göre, sevdiği için öğretmenlik mesleğini seçtiğini söyleyen öğretmen adaylarının, boşta kalmamak için ve imkanları iyi olduğu için mesleği seçtiğini söyleyen öğretmen adaylarından daha olumlu tutum puanına sahip olduğu saptanmaktadır.

Tablo 6. Değer Boyutunda Mesleği Seçme Nedenlerine iliş̧in Veriler

\begin{tabular}{|c|c|c|c|c|c|}
\hline Alt Boyut & Grup & Grup Adı & $\mathrm{N}$ & $\overline{\mathrm{X}}$ & ss \\
\hline \multirow{6}{*}{ 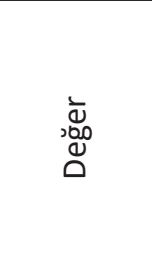 } & 1. & Sevdiğim için seçtim. & 63 & 4.56 & 0.41 \\
\hline & 2. & Boşta kalmamak için seçtim. & 29 & 3.85 & 1.00 \\
\hline & 3. & İmkânları iyi olduğu için seçtim. & 10 & 4.88 & 0.23 \\
\hline & 4. & Ailem istediği için seçtim. & 8 & 4.46 & 0.24 \\
\hline & 5. & Diğer & 5 & 4.52 & 0.39 \\
\hline & & Toplam & 115 & 4.40 & 0.68 \\
\hline
\end{tabular}

Tarih öğretmeni adaylarının mesleğe ilişkin tutum ölçeğinin değer alt boyutundan elde edilen verilerde "meslek seçim nedenleri” yönünden fark olup olmadığını incelemek amacıyla Tek Yönlü Varyans Analizi (ANOVA) yapılmıştır. Varyans analizi sonucunda tutumlarda farklılığın belirlendiği durumlarda, farklılığın hangi gruplar arasında gerçekleştiğini ortaya koymak için Kruskall Wallis-H $(\mathrm{KWH})$ çoklu karşılaştırma testi uygulanmıştr. Analizlere ilişkin veriler ve yorumlamalar aşağıda sunulmuştur. 
Tablo 7. Değer Boyutuna İlişkin ANOVA Sonuçları

\begin{tabular}{|c|c|c|c|c|c|c|c|}
\hline \multirow{2}{*}{ Varyansın Kaynağı } & \multirow{2}{*}{ Kareler Toplamı } & \multirow{2}{*}{$\mathrm{sd}$} & \multirow{2}{*}{ Kareler Ortalaması } & \multirow{2}{*}{$F$} & \multirow{2}{*}{$P$} & \multicolumn{2}{|c|}{ Homojenlik } \\
\hline & & & & & & Levene & $\mathrm{p}$ \\
\hline Gruplar arası & 12.819 & 4 & 3.205 & 8.711 & .000 & & \\
\hline Gruplar içi & 40.472 & 110 & .368 & & & 33.652 & .000 \\
\hline Toplam & 53.291 & 114 & & & & & \\
\hline
\end{tabular}

Tablo 6'da ve 7'de tarih öğretmeni adaylarının “Öğretmenlik mesleği tutum ölçeği”nin "Değer" alt boyutuna ilişkin tutumları "mesleği seçme nedeni" faktörünü göre incelendiğinde anlamlı bir farklılık bulunsa da Levene istatistiği sonucunda maddelerin non-parametrik olduğu ve bunun sonucunda anlamlı bir farklılık görüldüğünden $[F(4-114)=8.711$; p $<0.05]$, parametrik olmayan Kruskall Wallis-H $(\mathrm{KWH})$ çoklu karşılaşttrma testi uygulanmıştr.

Tablo 8. Değer Boyutuna îlişkin Kruskall Wallis-H Testi (KWH) Sonuçları

\begin{tabular}{|c|c|c|c|c|c|c|c|}
\hline Alt Boyut & Grup & Grup Adı & $\mathrm{N}$ & Sıralar Ortalaması & $\mathrm{sd}$ & KWH & $\mathrm{p}$ \\
\hline \multirow{5}{*}{ 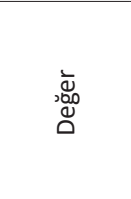 } & 1. & Sevdiğim için seçtim. & 63 & 62.10 & \multirow{5}{*}{4} & \multirow{5}{*}{18.014} & \multirow{5}{*}{.001} \\
\hline & 2. & Boşta kalmamak için seçtim. & 29 & 40.55 & & & \\
\hline & 3. & İmkânları iyi olduğu için seçtim. & 10 & 88.35 & & & \\
\hline & 4. & Ailem istediği için seçtim. & 8 & 51.69 & & & \\
\hline & 5. & Diğer & 5 & 59.90 & & & \\
\hline
\end{tabular}

Tablo 8'deki veriler incelendiğinde tarih öğretmeni adaylarının "Öğretmenlik mesleği tutum ölçeği”nin "Değer" alt boyutuna ilişkin tutumları "mesleği seçme nedeni" faktörüne göre incelendiğinde anlamlı bir farklılık görülmektedir $[\mathrm{KWH}(4)=18.014 ; \mathrm{p}<0.05]$.

Kruskall Wallis-H (KWH) çoklu karşılaştırma testi sonucunun anlamlı çıktığı durumlarda gruplar arasındaki farkın kaynağını belirlemek amacıyla ikili kombinasyonlar üzerinde Mann-Whitney U testinden yararlanılmıştır.

Tablo 9. Değer Boyutuna ilişkin Mann-Whitney U Testi Sonuçları

\begin{tabular}{|c|c|c|c|c|c|c|c|}
\hline Alt Boyut & Gruplar & $\mathrm{N}$ & Sıralar Ortalaması & Sıralar Toplamı & M-Whitney U & Z & $p$ \\
\hline \multirow{10}{*}{ 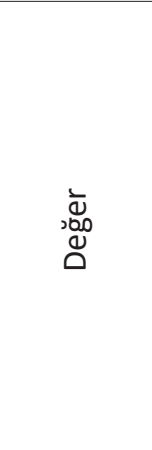 } & 1. & 63 & 52.13 & 3284.00 & \multirow{2}{*}{559.000} & \multirow{2}{*}{-3.016} & \multirow{2}{*}{.003} \\
\hline & 2. & 29 & 34.28 & 994.00 & & & \\
\hline & 1. & 63 & 34.56 & 2177.50 & \multirow{2}{*}{161.500} & \multirow{2}{*}{-2.550} & \multirow{2}{*}{.011} \\
\hline & 3. & 10 & 52.35 & 523.50 & & & \\
\hline & 2. & 29 & 16.31 & 473.00 & \multirow{2}{*}{38.000} & \multirow{2}{*}{-3.513} & \multirow{2}{*}{.000} \\
\hline & 3. & 10 & 30.70 & 307.00 & & & \\
\hline & 3. & 10 & 12.30 & 123.00 & \multirow{2}{*}{12.000} & \multirow{2}{*}{-2.696} & \multirow{2}{*}{.007} \\
\hline & 4. & 8 & 6.00 & 48.00 & & & \\
\hline & 3. & 10 & 9.50 & 95.00 & \multirow{2}{*}{10.000} & \multirow{2}{*}{-2.073} & \multirow{2}{*}{.038} \\
\hline & 5. & 5 & 5.00 & 25.00 & & & \\
\hline
\end{tabular}

Tablo 9'daki Mann-Whitney U testine ilişkin veriler incelendiğinde tarih öğretmeni adaylarının "Öğretmenlik mesleği tutum ölçeği" nin "Değer" alt boyutuna ilişkin tutumları "mesleği seçme nedeni" faktörüne göre, 1.grupla ile 2.grup $(U=559.000 p<0,05)$, 1.grupla ile 3.grup $(U=161.500 p<0,05)$, 2.grupla ile 3.grup $(U=38.000 p<0,05)$, 3.grupla ile 4.grup $(U=12.000 p<0,05)$ ve 3.grupla ile 5.grup $(U=10.000 p<0,05)$ arasında anlamlı bir farklılık görülmektedir. Sonuç olarak mesleği sevdiği için seçen adayların boşta kalmamak için seçen adaylara göre; mesleği imkanları iyi olduğu için seçen adayların ise mesleği sevdiği için, boşta kalmamak için, ailesi istediği için ve diğer sebeplerle seçen adaylara göre öğretmenlik mesleğine daha fazla değer verdiği tespit edilmiştir.

Tablo 10. Uyum Boyutunda Mesleği Seçme Nedenlerine İlişkin Veriler

\begin{tabular}{cclccc}
\hline Alt Boyut & Grup & Grup Adı & $\mathrm{N}$ & $\overline{\mathrm{X}}$ & ss \\
\hline & 1. & Sevdiğim için seçtim. & 63 & 4.06 & 0.61 \\
& 2. & Boşta kalmamak için seçtim. & 29 & 3.64 & 0.60 \\
$\bar{\Sigma}$ & 3. & Imkânları iyi olduğu için seçtim. & 10 & 3.04 & 0.74 \\
& 4. & Ailem istediği için seçtim. & 8 & 3.42 & 0.55 \\
& 5. & Diğer & 5 & 4.28 & 0.70 \\
& & Toplam & 115 & 3.83 & 0.70 \\
\hline
\end{tabular}


Tarih öğretmeni adaylarının mesleğe ilişkin tutum ölçeğinin "uyum" alt boyutundan elde edilen verilerde "meslek seçim nedenleri" yönünden fark olup olmadığını incelemek amacıyla Tek Yönlü Varyans Analizi (ANOVA) yapılmıştır.

\section{Tablo 11. Uyum Boyutuna ilişskin ANOVA Sonuçları}

\begin{tabular}{lcccccc}
\hline Varyansın Kaynağı & Kareler Toplamı & sd & Kareler Ortalaması & F & P & Fark \\
\hline Gruplar arası & 13.047 & 4 & 3.262 & 8.375 & .000 & $1-2,1-3,3-5$ \\
Gruplar içi & 42.839 & 110 & .389 & & & \\
Toplam & 55.887 & 114 & & & & \\
\hline
\end{tabular}

Tablo 10 ve 11'deki veriler incelendiğinde tarih öğretmeni adaylarının “Öğretmenlik mesleği tutum ölçeği”nin "Değer" alt boyutuna ilişkin tutumları "mesleği seçme nedeni" boyutunda incelendiğinde 1. grup ile 2. grup; 1. grupla 3. grup ve 3. grupla 5. grup arasında anlamlı bir farklılık görülmektedir $[F(4-110)=8.375 ; p<0.05]$. Test sonucuna göre mesleği seçme nedeni yönünden 1.grupta yer alan öğretmen adayları 'tamamen katılıyorum' ( $\bar{X}=4.06)$ düzeyinde görüş bildirirken 2. grupta yer alan öğretmen adayları 'kathlıyorum' ( $\bar{X}=3.64)$, 3. grupta yer alan öğretmen adayları 'katılıyorum' ( $\overline{\mathrm{X}}=3.04)$ ve 5.grupta yer alan öğretmen adayları da 'tamamen kathlıyorum' $(\overline{\mathrm{X}}=4.28)$ düzeyinde görüş bildirmişlerdir. Bu sonuca göre, diğer seçeneği işaretleyen öğretmen adaylarının, sevdiği için, boşta kalmamak için ve imkanları iyi olduğu için mesleği seçtiğini söyleyen öğretmen adaylarından daha çok mesleğe uyum sağladığını söylemek yanlış olmayacaktır. Diğer seçeneği işaretleyen adayların ifadeleri; hepsi, bana en yakın meslek, etki alanı geniş bir meslek, en sevecen meslek, şans ve kısmet ve insanların ihtiyaçlarına cevap veren meslek olduğu için seçtim şeklindedir.

\section{Sonuçlar}

Öğretmen adaylarııın öğretmenlik mesleğine ilişkin bakış açılarının ve tutumlarının mesleki başarılarını etkileyebileceği, bu sebeple araştırma sonuçlarına göre öğretmen eğitiminin şekillendirilmesi gerektiği noktasından hareketle planlanan çalışmada; tarih öğretmeni adaylarının öğretmenlik mesleğine ilişkin tutumları sorgulanmıştr. Daha önce spesifik olarak tarih öğretmeni adaylarıyla böyle bir çalışmanın yapılmamış olması da araştırmayı anlamlı kılmaktadır. Katılımcılardan elde edilen verilere göre araştırmada aşağıda yer alan sonuçlara ulaşıımıştır:

Öğretmenlik mesleği tutum ölçeğinden elde edilen puanlara göre çalışma grubunda yer alan tarih öğretmeni adaylarının genel anlamda öğretmenlik mesleğine ilişkin olumlu bir bakış açısına sahip olduğu tespit edilmiştir. Başbay, Ünver ve Bümen (2009), Altınkurt, Yılmaz ve Erol (2014), Gülşen ve Gündüz (2016), Yılmaz, Bayraktar ve Gökkurt Özdemir (2017) tarafindan yapılan çalışmalarda da benzer sonuçlara ulaşıldığı görülmüştür.

Çalışmada yer alan kadın tarih öğretmeni adaylarının öğretmenlik mesleğine yönelik sevgilerinin ve öğretmenlik mesleğine yönelik uyumlarının, erkek tarih öğretmeni adaylarına göre daha yüksek olduğu söylenebilir. Kadın tarih öğretmeni adaylarının öğretmenlik mesleğine ilişkin tutum puan ortalamasının sevgi ve uyum kategorilerinde erkek öğretmen adaylarının ortalamasından daha yüksek olması, kadınların tutumlarının erkeklerin tutumlarına nazaran daha olumlu olduğunu göstermiştir. Bu bulgu, Çapa ve Çil (2000), Semerci ve Semerci (2004), Demirtaş ve Arkadaşları (2008), Bulut (2009), Aksoy (2010), Karatekin, Merey ve Keçe (2015)'nin yapmış oldukları araştrrma bulguları ile paralellik göstermiştir. Aynı öğretmenlik mesleğine yönelik tutum ölçeğini (Çetin, 2006) kullanan araştırmalarda da sevgi, değer ve uyum boyutlarında kadın öğretmen adaylarının lehine anlamlı sonuçlara ulaşıldığı görülmüştür (Bahadır ve Tuncer, 2017; Yalçın ve Özgen, 2017). Öğretmenlik mesleğine ilişkin tutum araştırmalarının genelinde kadın öğretmen adaylarının mesleki tutum puanlarının erkek öğretmen adaylarına oranla yüksek olmasında Türk toplumunda öğretmenlik mesleğinin bir kadın mesleği olarak algılanmasının etkili olduğu söylenebilir. Bu algı kadın öğretmen adaylarının mesleğe ilişkin motivasyonlarını da etkilemektedir. Farklı araştırmalarda da bu sonuç dikkat çekmiştir (Çapa ve Çil, 2000; Bozdoğan, Aydın ve Yıldırım, 2007; Pehlivan, 2013; Yılmaz, Oğuz ve Altınkurt, 2017; Çakır ve Akkaya, 2017).

Sevdiği için öğretmenlik mesleğini seçtiğini söyleyen öğretmen adaylarının, boşta kalmamak için ve imkanları iyi olduğu için mesleği seçtiğini söyleyen öğretmen adaylarından daha yüksek tutum puanına sahip olduğu görülmüştür. Mesleği sevdiği için seçen adayların boşta kalmamak için seçen adaylara göre; mesleği imkanları iyi olduğu için seçen adayların ise mesleği sevdiği için, boşta kalmamak için, ailesi istediği için ve diğer sebeplerle seçen adaylara göre öğretmenlik mesleğine daha fazla değer verdiği tespit edilmiştir. Diğer seçeneği işaretleyen öğretmen adaylarının, sevdiği için, boşta kalmamak için ve imkanları iyi olduğu için mesleği seçtiğini söyleyen öğretmen adaylarından daha çok mesleğe uyum sağladığını söylemek yanlış olmayacaktı. Diğer seçeneği işaretleyen adayların ifadeleri; "hepsi, bana en yakın meslek, etki alanı geniş bir meslek, en sevecen meslek, şans ve kısmet ve insanların ihtiyaçlarına cevap veren meslek olduğu için seçtim" şeklindedir. Buradaki yorumların da çoğunlukla mesleği benimseyen ifadeler olduğu dikkat çekicidir. 
Aksoy (2010) tarafinda yapılan araştırmada da öğretmenlik yapmayı isteyerek seçen adayların mesleğe ilişkin tutumlarının daha yüksek olduğu yönünde bir sonuca ulaşılmıştır. Özder, Konedralı ve Zeki, (2010) tarafindan yapılan çalışmada da öğretmen olmaya istekli olan adayların iş garantisi ve çalışma şartları dolayısıyla mesleği seçenlere göre tutum puanlarının yüksek olduğu yönündedir. Kyriacou ve Kunc (2007) tarafindan yapılan çalışmada ise öğretmenlerin mesleğe yönelik tutumlarını belirlemede mesleğin ekonomik getirilerinin etkili olduğu sonucuna ulaşılmıştr.

Sonuç olarak formasyon programı öğrencilerinin öğretmenlik mesleğine ilişkin tutumlarının yüksek olduğu belirlenmiştir. Alan yazındaki araştırmalarla da benzer sonuçlara ulaşıldığı görülmüştür. Formasyon programının öğrencilerinin öğretmenlik mesleğine ilişkin tutumlarının olumlu yönde yüksek olması dikkat çekicidir. Edebiyat fakültelerinin misyonları arasında öğretmen yetiştirme amacı olmamasına rağmen bu fakülteleri tercih eden öğrencilerin nihai hedeflerinin öğretmen olmak olduğunu söylemek yanlış olmayacaktır. Ayrıca bu öğrencilerin pedagojik formasyon programına kayıt yaptırabilmeleri ve öğretmen olarak istihdam edilebileceklerine ilişkin umutları öğretmen adaylarının motivasyonlarını ve mesleğe ilişkin tutumlarını olumlu yönde arttırmaktadır. Yürütülen formasyon eğitiminin de öğretmen adaylarının öğretmenlik mesleğine ilişkin tutumlarına katkı sağladığını söyleyebiliriz.

\section{5. Öneriler}

Öğretmenlik bir meslek olarak bilinç gerektirmekte ve mesleği seçen bireylerin bu mesleğin gerekleri için var güçleriyle çalışmaları beklenmektedir. Öğretmenin elinden çıkacak ürünün 'insan' olması da bu durumu zorunlu kılmaktadır. Bu sebepledir ki, mesleği seçenler ve mesleğe yönlendirilenler özel bir intimamla yetiştirilmelidir. Her ne kadar formasyon programı ile olumlu öğretmenlik algılarına sahip öğretmen adaylarının yetiştirildiği ifade edilse de bunun genel geçer bir bilgi olmadığı düşünülerek, öğretmen yetiştirmenin planlı, düzenli ve süreğen bir anlayışla şekillendirilmesinin mesleğin niteliğinin artması ve ülkenin geleceği açısından yararlı olacağı söylenebilir.

Bu sonuçlar doğrultusunda aşağıda yer alan öneriler sunulmuştur.

- Çalışmanın farklı üniversitelerdeki tarih öğretmen adaylarıyla da tekrarlanarak sonuçların karşılaştırılması yararlı olacaktır.

- Öğretmen yetiştirme konusunda planlı-programlı ve sistemli bir yol izlenerek ortaöğretimden itibaren öğretmen olmak isteyen bireylere bir yol haritası çizilebilmelidir.

- Öğretmen yetiştirme sürecinde küçük değişiklik hamleleri dışında uzun soluklu bir program uygulamasına gidilmeli, program geliştirme mantı̆̆ı izlenmelidir.

- Öğretmenlik mesleğinin seçiminde akademik başarı puanlarının yanı sıra mesleğe ilişkin tutumların da dikkate alınması önemlidir.

- Tarih öğretmeni adaylarının öğretmenlik mesleğine ilişkin tutumlarının olumlu yönde gelişmesi için lisans eğitimlerinin ilkyıllarından itibaren tarih öğretimine ilişkin çalışmaların yapılması ve teşvik edilmesi sağlanmalıdır.

\section{Kaynakça}

Aksoy, M. E. (2010). Öğretmen adaylarının öğretmenlik mesleğine ilişkin tutumları. Sosyal Bilimler Araştrma Dergisi, 2, 197-212.

Altınkurt, Y., Yılmaz, K. ve Erol, E. (2014). Pedagojik formasyon programı öğrencilerinin öğretmenlik mesleğine yönelik motivasyonları. Trakya Üniversitesi Eğitim Fakültesi Dergisi, 4(1), 48-62.

Ayas, A. (2013). “Eğitimle Ilgili Temel Kavramlar”. Eğitim Bilimlerine Giriş. Ed. H. Özmen- D. Ekiz. Pegem Akademi. 2-12.

Bahadır, F. ve Tuncer, M. (2017). Öğretmen adaylarının bilimsel araştırma öz-yeterlikleri ve öğretmenlik mesleğine yönelik tutumları açısından değerlendirilmesi. Openaccess.firat.edu.tr (13.04.2018)

Başbay, M., Ünver, G. ve Bümen, N. T. (2009). Ortaöğretim alan öğretmenliği tezsiz yüksek lisans öğrencilerinin öğretmenlik mesleğine yönelik tutumları: Boylamsal bir çalışma, Kuram ve Uygulamada Eğitim Yönetimi, 15/59, 345-366.

Bozdoğan, A. E., Aydın, D. ve Yıldııım, K. (2007). Öğretmen Adaylarııı Öğretmenlik Mesleğine iliş̧kin Tutumları. Ahi Evran Üniversitesi Kırşehir Eğitim Fakültesi Dergisi, 8(2), 83-97.

Bulut, i. (2009). Öğretmen adaylarının öğretmenlik mesleğine ilişkin tutumlarının değerlendirilmesi (Dicle ve Fırat Üniversitesi Örneği), Dicle Üniversitesi, Ziya Gökalp Eğitim Fakültesi Dergisi, 14, 13-24.

Çakır, S. ve Akkaya, R. (2017). İlköğretim matematik öğretmen adaylarının öğretmenlik mesleğini tercih etme nedenleri ve öğretmenlik eğitimi ile ilgili beklentileri. Abant Izzet Baysal Üniversitesi Eğitim Fakültesi Dergisi, 17(1), 78-98.

Çapa, Y. ve Çil, N. (2000). Öğretmen adaylarının öğretmenlik mesleğine yönelik tutumlarının farklı değişkenler açısından incelenmesi, Hacettepe Üniversitesi Eğitim Fakültesi Dergisi, 18, 69-73

Çetin, Ş. (2006). Öğretmenlik mesleği tutum ölçeğinin geliştirilmesi (Geçerlik ve güvenirlik çalışması). Gazi Üniversitesi Endüstriyel Sanatlar Eğitim Fakültesi Dergisi, 18, 28-37. 
Demirel, Ö. (2009). Öğretmen sanat: Öğretim ilke ve yöntemleri. Pegem Akademi Yayıncılık.

Demirtaş, H., Cömert, M. ve Özer, N. (2008). Öğretmen adaylarının öğretmenlik mesleğine yönelik tutumlar ile öz yeterlik algıları arasındaki ilişki, Proceedings of International conference on Educational Science ICES'08 1, 23-25 North Cyprus.

Eraslan, L. ve Çakıcı, D. (2011). Pedagojik formasyon programı öğrencilerinin öğretmenlik mesleğine yönelik tutumları. Kastamonu Eğitim Dergisi 19/2, 427-438.

Gülşen, C. ve Gündüz, H. Ç. (2016). Pedagojik formasyon eğitimi alan öğretmen adaylarının öğretmenlik mesleği ve öğretmenlik uygulamasına yönelik görüşleri. International Journal of Social Sciences and Education Research. 2(3), 870-883.

İlhan, A. Ç. (2004). 21. yüzyılda öğretmen yeterlikleri. Bilim ve Aklın Aydınlığında Eğitim Dergisi, 58, 40-45.

Kağıtçıbaşı, Ç. (1988). Insan ve Insanlar, Evrim Basım Yayım, İstanbul.

Karasar, N. (2016). Bilimsel Araştırma Yöntemi. Ankara: Nobel Akademik Yayıncılık.

Karatekin, K., Merey, Z. ve Keçe, M. (2015). Sosyal bilgiler öğretmen adaylarının öğretmenlik mesleğine yönelik tutumları. YYÜ Eğitim Fakültesi Dergisi, 12(1), 70-96.

Kyriacou, C. and Kunc, R. (2007). Beginning teachers' expectations of teaching. Teaching and Teacher Education, 23, $1246-1257$.

MEB ÖYGGM. (2017), Öğretmen Yeterlikleri. MEB Yayını. Ankara.

MEB. (1739). Milli Eğitim Temel Kanunu-Mevzuat. www.mevzuat.gov.tr/MevzuatMetin/1.5.1739.pdf

Ocak, G. (2016). Meslek olarak öğretmenlik. Eğitim Bilimine Giriş (Ed. K. Keskinkılıç). Ankara: Pegem Akademi. 37-85.

Özder, H., Konedralı, G. ve Zeki, C. P. (2010). Öğretmen adaylarının öğretmenlik mesleğine yönelik tutumlarının çeşitli değişkenler açısından incelenmesi. Kuram ve Uygulamada Eğitim Yönetimi Dergisi, 16(2), 253-275.

Papanastasiou, C. (2002). School, teaching and family influence on student attitudes toward science: based on TIMSS data for cyprus. Studies in Eucational Evaluation, 28, 71-86.

Pehlivan, K. B. (2013). Sınıf öğretmeni adaylarının sosyo-kültürel özellikleri ve öğretmenlik mesleğine yönelik tutumları üzerine bir çalışma. Mersin Üniversitesi Eğitim Fakültesi Dergisi, 4(2), 151-168.

Sayar, K. (2017). Neden depresyona giriyoruz. http://www.kemalsayar.com/KatagoriDetay-Neden-depresyona-giriyoruz-125.html.(04.01.2018)

Semerci, N. ve Semerci, Ç. (2004). Türkiye'de öğretmenlik tutumları, Fırat Üniversitesi Sosyal Bilimler Dergisi,14(81), 137-146.

Statistical Package for Social Sciences (SPSS) 23.0 paket programı

Taşkın Şahin, Ç. ve Hacıömeroğlu, G. (2010). İlköğretim bölümü öğretmen adaylarının mesleğe yönelik tutumları: Nicel ve nitel verilere dayalı bir inceleme. İlköğretim Online (Elementary Education Online), 9(2), 922-933.

Yalçın, O. M. ve Özgen, B. (2017). Okul öncesi öğretmenliği bölümü öğrencilerinin mesleğe yönelik tutumlarının ve öz güven düzeylerinin incelenmesi (KKTC). Eğitim Kuram ve Uygulama Araştırmaları Dergisi, 3(3), 63-80.

Yılmaz, M., Bayraktar, R. ve Özdemir, B. G. (2017). Pedagojik formasyon eğitimi alan öğretmen adaylarının mesleğe ilişkin tutumlarının incelenmesi. Eğitim ve Toplum Araşttrmaları Dergisi, 4(2), 50-58.

Yılmaz, K., Oğuz, A. ve Altınkurt, Y. (2017). Öğretmenlerin liderlik davranışları ile öğrenen özerkliğini destekleme davranışları arasındaki ilişki. Hacettepe Üniversitesi Eğitim Fakültesi Dergisi, 32(3), 659-675. 